\title{
Development, trans/modernities, and the politics of theory
}

\author{
Arturo Escobar
}

\section{Latin America: dreaming the impossible?}

Five or ten years from now, the performance of the allegedly leftist regimes in Latin America (particularly those of Venezuela, Ecuador, and Bolivia and, to varying degrees, those of Argentina, Paraguay, Nicaragua, Chile, Uruguay, and Brazil) will be assessed in terms of the extent to which they were able to bring about a reduction of poverty, sustained rates of growth, and a measure of democratization in their countries, including less inequality and more inclusive policies, particularly toward ethnic minorities. In other words, they will be assessed in terms of modernization and development. These criteria apply even to the somewhat novel proposals by some of these regimes to transform the state and society, including a deepening of democracy, toward direct, substantive, and integral democracy; anti-neoliberal political and economic projects; the construction of pluricultural and plurinational states; and, to a lesser extent, development models that involve an explicit dimension of ecological sustainability. So far, the main vehicles to achieve these aims have been the high profile, and much contested, national constituent assemblies, a revamping of political parties and political power, and a range of more or less innovative social policies.

There is much that is worthwhile about these goals, particularly concerning the politics of redistribution and social justice that are central to government policies in Venezuela, Ecuador, Bolivia, and Argentina at present. ${ }^{1}$ A cursory look at the actual policies of all the leftist governments, however, suggests that they amount to alternative modernization projects rather than more radical forms of societal transformation. To borrow the expression of Alvaro García Linera, vice president of Bolivia, one could say that what is taking place in the region is a decided attempt to construct modernidades satisfactorias, that is, modernities where "the two conquests of equality" (Linera's expression, meaning equality of political rights and economic equality) have been secured for most of the population, and where the hegemony of one form of modernity (Euro-modernity) has been put in check. But even at the level of this seemingly straightforward criteria, some novel processes are taking place, including new kinds of regional integration, such as the Unión Sudamericana de $\mathrm{Na}$ ciones (Unasur) and the Alternativa Bolivariana para las Americas (ALBA, or Bolivarian Alternative for the Americas), a South American Bank, and the beginning of discussions about a common currency. All of these are, to a significant degree, elements in a concerted move toward greater independence vis-à-vis the United States and, of course, aim at making South America an important economic and ideological bloc in the global economy. Some of the new constitutions include pluralist conceptions of property and the economy and less economistic notions of devel- 
opment, for instance, in terms of buen vivir, or life with dignity.

These policies and reforms refer primarily to the state level. What is happening in the space of social movements and intellectual-activist circles, including in subregions such as southern Mexico, is another matter. Still, the bulk of these movements' thoughts and proposals fall within the "alternative modernizations" camp; this applies to many of the demands of indigenous peoples, peasants, afro-descendants, and the urban poor. Yet here and there one can hear unmistakable signs of other thoughts and projects. Where "here and there"? This question, as usual, becomes one of perspective, standpoint, engagement, and framework of analysis. What frameworks and engagements? Who one thinks with, from what perspective, and for what purposes become of primary importance to providing a different, and actually broader, interpretation of events, at least if one wants to incorporate the perspective of social movements in these interpretations.

Based on the thoughts and practices of some movements and the intellectuals close to these movements (particularly, but not solely, in the Andean region), one can advance the following working hypothesis: that the current social, economic, political, and cultural transformations going on in many parts of Latin America point to the existence of two potentially complementary but also competing projects: (1) alternative modernizations, based on an anti-neoliberal development model, potentially leading to a postcapitalist economy and an alternative form of modernity (Linera's modernidad satisfactoria); this project stems from the crisis of the neoliberal project of the past three decades. (2) decolonial projects, based on different sets of practices (e.g., communal, indigenous), leading to pluralist postcapitalist, postliberal, and poststatist societies and, potentially, to alternatives to modernity. This second project can be read most clearly from the crisis of modernity in the continent. The question then becomes: is it possible to go beyond capital (as the dominant form of economy), Euro-modernity (as the dominant cultural construction of socionatural life), and the state (as the central form of the institutionalization of the social)? Three scenarios, then: postcapitalist, postliberal, and poststatist. Needless to say, this second hypothesis would require a radical transformation of the pattern of power and knowledge that has characterized modern/ colonial societies until recently.

This hypothesis also means that the current moment needs to be interpreted in terms of a particular conjuncture defined by the articulation of a double crisis: the crisis of the neoliberal modernizing model of the past three decades, and the crisis of the project of bringing about modernity in the continent that has lasted for more than five hundred years. The second project emerges from this conjuncture, and it can plausibly be read from a number of social sources. First, there are a number of statements by well-known intellectuals and activists that unambiguously point in this direction. For Luis Macas, former leader of the largest indigenous confederation of Ecuador, CONAIE, "nuestra lucha es epistémica y política" (our struggle is epistemic and political). For Félix Patzi Paco, an Aymara sociologist and the first minister of education of Evo Morales's administration, the social movements in Bolivia are about "the total transformation of liberal society" (Public talk at University of North Carolina, November 17 2005). Even President Rafael Correa, in his inaugural speech of 15 January 2007, characterized his revolución ciudadana (citizen's revolution) as involving not an epoch of change but a change of epoch. And García Linera had the following to say about the need for a new constitution:

The Constituent Assembly is conceived of and was convoked to create an institutional order that corresponds to the reality of who we are. Up to now, each of our 17 or 18 constitutions has just tried to copy the latest institutional fashion-French, U.S., European. And it was clear that it didn't fit us, because these institutions correspond to other societies. We are indigenous and nonindigenous, we are liberal and 
communitarians, we are a profoundly diverse society regionally and a hybrid in terms of social classes. So we have to have institutions that allow us to recognize that pluralism. (Laura Carlsen, 16 November 2007; http://americas.irconline.org/am/4735).

Some academics and intellectuals similarly speak about un nuevo ciclo histórico (a new historical cycle), potentially leading to a significant renewal of democracy and development (e.g., Calderón 2007). In other words, if most revolutionary processes of the past still operated within the modern liberal model, what might be at stake in the transformations in Ecuador, Bolivia, and Venezuela in particular is the end of coloniality. This implies the construction of another societal project, free once and for all of its moorings in modernity/coloniality: in short, un giro decolonial (a decolonial turn; see CastroGómez and Grosfogel (2007) and the Latin American Modernity/Coloniality/Decoloniality group, MCD). Or, as Mario Blaser (2007) argues, if it is true that the left governments constitute attempts to recompose the project of modernity through a modernizing model that to a greater or lesser extent presents an alternative to the neoliberal model, the culturalpolitical projects of many of the region's social movements seem to overflow modernist criteria. According to Marisol de la Cadena (2007), when considering the recent indigenous forms of political mobilization, we need to start thinking about an ontological decentering of modern politics. There is an active debate on these concepts among indigenous and black intellectuals in the Andean countries, and intellectualactivists are working with, and writing about, some of these movements in the wider region (e.g., Ceceña 2008, Zibechi 2006, and the debates coming from movements such as Xochitl Leyva, Colectivo Situaciones, and the Madres de la Plaza de Mayo, to mention just a few of the most recent and prominent examples). To explain the above hypothesis more adequately, however, would require a much longer treatment (in preparation).

\section{The anthropology of development and the aporias of theory}

Development is a discourse and set of practices, an imperial intervention, a cultural construction of modern origin, a space of struggle over the terms of society and the economy, a desire on the part of many people the world over, and even the political and cultural struggles arising from the promises it makes and rarely fulfills. It is also a network of sites, a complex object of ethnographic investigation, a site of the construction of hegemony, and a site of contestation. As an expression of the modern constructs of progress and overcoming, of linear time and accumulation, of a liberalism based on private property and representative democracy, development is deeply entangled in the process of modernityfor some, it continues to be the main mechanism for enforcing such modernity, more apparent at a global scale today than ever.

Recent approaches to the ethnography of development projects have suggested that ethnographic research could be used to understand how policy really works, including the transformation that locals effect on projects, and that this understanding could be utilized to link the positive impetus of policy and the aspirations of the poor. This goal requires a detailed understanding of the relation between policy and practice as it is played out at many sites by a diversity of actors; this understanding is multipositioned as well as multisited, with the anthropologist as part insider and part outsider in several of these sites. The hope is that, given the reality of development, the critical ethnographer could illuminate the conditions for a more effective popular appropriation of the projects. These investigations, it is argued-a sort of hyperethnography, where the ethnographer sees the entire network at play and investigates in depth the main sites with their respective actors, cultural backgrounds, and dynamics of meaning-making and practical appropriation-should give us a more nuanced account of the flows of power than do previous poststructuralist analyses and would underscore how development operates as a mul- 
tiscale hegemonic process that, as such, is constantly transformed and contested.

By de-essentializing development and by looking carefully at the actor networks that, in the last instance, make up development projects, these newer approaches, it seems to me, solve some problems but create new puzzles. These puzzles, I would add, go well beyond the critical development studies (CDS) field; they affect much of contemporary theory, particularly those trends that emphasize a dispersed and networked logic as the basis of the production of the social; the problems in Northernbased contemporary critical theory are thus pervasive. I see four interrelated problems originating in four moves, or claims, found in this literature:

(1) Radical agentivity: everything/everybody has agency. The question thus becomes: How does one differentiate among various kinds of agency? What counts as significant agency? What happens to power?

(2) Radical connectivity: everything is connected to everything. New questions that arise include: How are things variously/differently connected? How do they fulfill different functions in a network of connectedness? What kinds of connections are, or might be, politically powerful, or particularly politically compromised? Whose attempts to connect, or disconnect, does one privilege?

(3) Radical contextuality: everything is contextdependent. The questions in this case are: What happens to difference? What takes place, in any given situation, that is not fully produced by capitalism, development, and modernity? In other words, how does one theorize those aspects of socionatural reality that, while greatly determined by hegemonies, are nevertheless not completely defined by them?

(4) Radical historicity: everything has a genealogy, a lineage. Question: What happens to what is genuinely emergent, unpredictable- to what cannot be read with the categories and experiences of the present, or of the modern social sciences, for that matter?
What does become of the politics of the virtual?

Final questions: In the newer approaches, how do authors construct their object of critique? What happens to praxis, that is, the connection between theory and practice, knowledge and action? $^{2}$

In the absence of dealing with these questions more effectively, it seems to me, some of the positions taken by the recent ethnographies of development, the state, modernity, and capitalism in the Anglo-Saxon academy in particular-where, again, development, the state, and modernity are shown to be heterogeneous, contested, networked, plural, and so forth, all of which makes a lot of sense-run the risk of falling into the trap of what Boaventura de Sousa Santos (2007) has called a "hermeneutics of cynicism," since nothing that any actor can do can ever amount to any significant challenge to what exists or even produce a significantly different thought. (In these works, it seems to me, development and modernity are, first, redefined in a way that deprives them of any historical coherence, let alone a unitary, social, and cultural logic and then, second, found ethnographically to be always plural, changing, and contested; there is thus a certain tautological argumentation at play. From this perspective, a question remains: What other kinds of theoretical and political claims can we possibly make with the insights of the ethnographies of modernity? In short, while very interesting in what they do, these works fail to reconstruct our understanding of the categories to which they refer: development, the state, modernity, capitalism, and so forth.) As a response, Santos advocates for a "hermeneutics of emergence," one that expands the range of experiences that could plausibly be conceived as sources of counterhegemonic processes. I would add that this hermeneutics involves a renewal of our efforts to theorize difference, and the investigating of those experiences where difference is mobilized politically to subvert hegemonies in ways that might contribute to constructing worlds and knowledges otherwise. To do so, however, requires thinking about theory, 
and the world, in altogether different wayswhich is, in my opinion, precisely what is at stake in some of the new movements and in some of the approaches being developed "here and there" by activists and intellectuals with, within, or close to movements.

\section{Modernity, modernities, non-modernities}

Modernity, however we define it, is part and parcel of the tradition that needs to be reoriented if different understandings of development are to be crafted, or even made visible. Discourses of globalization and development are, themselves, subsidiary to visions of modernity; modernity thus remains a key political and cultural question. For most analysts, globalization is-can only be-the universalization of modernity: in short, "modernity writ large" (Blaser, forthcoming). It seems impossible to imagine it otherwise. Schematically, there could be said to be three main positions regarding modernity: (1) modernity as universal process of European origin (intraEuro/American discourses); (2) alternative modernities (locally specific variations of the same universal modernity); and (3) multiple modernities, that is, modernity as multiplicity without a single origin or cultural home. In this latter view, modernity emerged from multiple intersecting processes, did not have a single origin, and has followed multiple trajectories. The modern, in this way, is an always ongoing struggle to define the real in terms of articulations of time and space, presence and change, lasting structures and the experience of the everyday. In other words, not every modernity is Euro-modernity, and multiple modernities can thus be reclaimed as an ontological and political project. By deessentializing modernity more radically than in most other works, this position-most cogently articulated currently by my colleague at Chapel Hill, Lawrence Grossberg (2007)_opens up new possibilities for rethinking the modern. This is another way of delinking modernity from the tight embrace by the West and locating possibilities for remaking it everywhere. ${ }^{3}$
From an MCD perspective, there is a fourth possibility: modernity/coloniality, or rather modernities/colonialities/decolonialities. From this perspective, the Colombian Pacific as much as Western Europe or anyplace else in the world is modern/colonial and, of course, potentially the site of decolonial projects. The 'origin' of modernity is always the origin of modernity/ coloniality/decoloniality; this is because one of the main postulates of the framework is that we all live in a single, albeit structurally heterogeneous, modern/colonial world system. It would take a much longer discussion to show that one corollary that emerges from this framework is that of alternatives to modernity or transmodernity; this means a discursive space in which the idea of a single modernity has been suspended at an ontological level-where Europe has been effectively provincialized, that is, displaced from the center of the historical and epistemic imagination, and where the examination of concrete modernities, symmetrical projects, and decolonial processes can be started in earnest from the perspective of epistemic difference. This leaves us with a view of multiple modernities or multiple MCDs as coexisting theoretical possibilities, to be maintained in tension.

One hypothesis that is currently being articulated in some Latin American spaces, particularly (but not solely) from the perspective of indigenous uprisings and mobilizations, is that underlying the more visible transformations is a stirring of entire ensembles of actors, networks, and practices that are ontologically different from the dominant Euro-modern ones-that is, the uprising of different worlds, different ontologies, particularly worlds that are more relational and communal. Here we return to the hypothesis of cultural construction, practices, and, potentially, institutions that are postcapitalist, postliberal, and post(modern) state. One might call it "the revenge of the multiplicities"; these ontologies, while distinct and often opposed to the modern, have lived with it and are thus more prepared than the Euro-modern ontologies to live in a pluriverse-indeed, they inhabit a pluriverse, often against all odds. From their deeply relational ontologies (as opposed to the funda- 
mentally dualistic, objectivist, and rationalist ontologies of dominant modernities), indigenous movements might indeed be able to deterritorialize the state, liberal society, and the capitalist economy to some noticeable degree. Many questions arise from this hypothesis, as far as states and popular organizations are concerned: Can existing relational and communal systems reach a stable expansion of their noncapitalist practices and nonstate forms of power? Can their practices of economic, ecological, and cultural difference be institutionalized in some fashion, without falling back into dominant modernist forms (Escobar 2006)? Can communitarian logics ever be the basis for an alternative, and effective, institutionalization of the social? Can the relational worlds envisioned by, say, the Zapatistas and many other social movements and intellectuals be arrived at through the construction of nonstatist, postcapitalist, and postliberal local and regional autonomies? And can these alternatives find a way to coexist, in mutual respect and tolerance, with what until now have been dominant, and allegedly universal, modern forms of life, even while they are being sabotaged by the latter (as in Bolivia and elsewhere)? A measure of success would imply the emergence of the seemingly ever-elusive goal of a genuinely plural society. A final question insinuates itself: Can the emergent cultural-political subjects in Latin America reach an activated and stable condition of alterity capable of reconstituting social structures from within, along the lines of pluralism and pluriversality?

\section{Back to theory one more time}

There is always a close connection between social reality, the theoretical frameworks we use to interpret it, and the sense of politics and hope that emerges from such an understanding. Our hopes and politics are largely the result of the particular framework through which we analyze the real. This connection is often overlooked; however, it is brought to the fore in times of heightened struggles. We might be going through one such period at present, in which we see both unprecedented social processes and an eagerness for novel languages and categories. As is often the case, the better-known theories are not yet at the point where they can say something radically new because the languages at their disposal do not allow it. Many of these languages are indeed disempowering of these more radical intentions.

It would seem as if from the depths of the social an urge to revamp social theory were springing more intensely than is usually the case. There is one crucial difference as compared with similar theoretical moments of the recent past: the cohort of those engaged in the production of new theories has expanded well beyond the usual suspects in the (predominantly Northern) academies. The complex conversations that are happening among many kinds of knowledge producers worldwide are themselves a hopeful condition of theory at present. A second feature is that this urge addresses the need to transform not only the contents of theory, but also its very form; in the last instance, what is at stake is the transformation of our understanding of the world in ways that allow us to contribute to the creation of different worlds. More philosophically, this means that a main feature of the current wave of critical theory is that it is concerned with questions of not only epistemology but also ontology, that is, basic questions about the nature of the world; in other words, today's critical theories are fueled by a fundamental scrutiny of the kinds of entities that modern theories have assumed to exist and, concomitantly, the construction of theories based on different ontological commitments. ${ }^{4}$ In this way, the decolonial turn is also an epistemic turn, a turn toward different configurations of knowledge, ones that would be linked, and contribute to, worlds and knowledges otherwise.

There is one final aspect I would like to mention in terms of the politics of theory. The ethnographies of development have done much to bring into visibility the transnational expert communities whose training, interests, tastes, orientations, and economic and political goals coincide enough to keep the development actor networks going, and often well oiled. As the en- 
vironmentalist and activist Larry Lohmann put it in the context of the Dag Hammarskjöld Foundation's What Next project, "at each stage, specialists in new fields are called in to create their own roles in the story of the global application of expertise" (2006: 150); hence the need for a renewed awareness of the politics of expertise that leads to a practice of "forming working alliances that can engender complexes of new practices" (ibid.: 175). As Lohmann says, we need to call standard rationality, common sense, and pervasive dualisms into question through "a performance art requiring practice, experience, intuition, flexibility, improvisation, sensitivity to historical and political circumstances, a sense of what lies over the horizon, and the ability to handle unforeseen consequences" (ibid.: 156).

This call resonates with Gibson-Graham, who, toward the end of A postcapitalist politics, adumbrates the possibility of building community economies "as a practice of (post)-development" (2006: 192). Their framework of a diverse economy might constitute one possible "alternative set of 'dynamic principles of development"” (ibid.: 195). Their dream is for a moment when "the development project no longer entails simply (painfully) submitting to the demanding logic of global capitalism, but becomes instead an ethical and political engagement-a sometimes difficult and conflictual process of experimenting with, fostering, exploring, connecting, expanding, and reworking the heterogeneous and scattered elements of a diverse (becoming community) economy" (ibid.). They envision a collective disidentification with capitalism, to which we can add development and modernity in their more dominant and conservative forms. To this end, we need to cultivate ourselves more explicitly as "theorists of possibility" (ibid.: xxvii). Perhaps one can say that "another academy is possible," as some say in some parts of South America today, where a number of alternative educational spaces are emerging ("pluriversities," indigenous universities, universities of resistance, and so forth). In these spaces, the thought of multiple worlds and ontologies, and multiple forms of theory, are being harbored and nourished.

\section{Acknowledgments}

Many of the ideas in this article have been generated in conversations in recent months with a number of friends and colleagues, among whom I would like to highlight Marisol de la Cadena and Mario Blaser. I would also like to mention Eduardo Gudynas (CLAES, Montevideo), Alejandro Grimson (IDAES, Buenos Aires), Margarita Lopez Maya (CENDES, Universidad Central de Venezuela), Subir Sinha, Pieter de Vries, Lynn Stephen, and John Pickles and Larry Grossberg. My thanks also to the faculty and $\mathrm{PhD}$ students at the main places where I spent my sabbatical leave (2007-8): Wageningen University in the Netherlands (Department of Rural Development Sociology); the Instituto de Altos Estudios Sociales, IDAES, Universidad Nacional de San Martin, Buenos Aires; and the University of Oregon, Eugene (Wayne Morse Center for Law and Politics). Thanks also to friends from the Latin American MCD group, and the Chapel Hill Social Movements Working Group. Finally, thanks to Gavin Smith for the invitation to contribute to this debate. I have used in this piece some ideas from my afterword to the volume by Sadhvi Dar and Bill Cooke (2008). The hypothesis about the Latin American transformations at present was the subject of a lecture at the University of Oregon's Wayne Morse Center for Law and Politics (a version of this talk can be found at www.morsechair.uoregon.edu/).

Arturo Escobar is Kenan Distinguished Professor of Anthropology at the University of North Carolina in Chapel Hill. His main interests are political ecology, the anthropology of development, social movement theory, and science and technology studies. Over the past ten years, he has worked closely with several social movements in the Colombian Pacific and with the Rome-based Society for International Development (SID) on projects on globalization, culture, women, environment, and place.

E-mail: aescobar@email.unc.edu.

Mailing address: Department of Anthropology, CB 3115, University of North Carolina, Chapel Hill, NC 27599, USA. 


\section{Notes}

1. I will not discuss here the many tensions and contradictions that inhabit the redistributive policies of these governments, their dependence on productivist logics and favorable international prices for primary commodities, and the limits of their goals when confronted with resistance by organized right-wing or capitalist groups. There is still a tremendous lack of studies to analyze the effectiveness of social policies in this regard. In a similar vein, the extent to which the newly sought economic and political integration is effectively achieved through concrete policies, and without introducing new regional imbalances, remains to be seen, and will also have to be assessed on its own terms.

2. As I mentioned, these predicaments affect much of the new materialist and neorealist sociologies. Notions such as "cutting the network" (Strathern 1996) and "arbitrary closure" are among the few notions that deal with the epistemologicalempirical problem posed by the four predicaments. I would add one more, which has to do with positionality, that is, with understanding how activists in particular deal with this question, e.g., how they cut their networks and how they arrive, practically within every strategy, at arbitrary closure, which is not, however, less "sophisticated" than that of the ethnographer or academic (if anything, often it is the opposite as academics arrive at closure unwittingly from the perspective of canons and disciplinary traditions that have little bearing on social and political processes where concrete socionatural worlds are struggled over).

3. Grossberg's (2007) reading is much more complex than I can explain here; it includes an analysis of social, structural, and ontological discourses of modernity; a theory of modernity as virtual multiplicity, following Deleuze and Guattari; and a diagram of modernity in terms of the dialectic of space and time, structure and experience, change and presence, event and everyday life.

4. Some see this turn in theory in terms of emergent 'flat alternatives', in that they dissolve the strong categories of much of modern social theory (essential identities and transhistoric or transcendental entities, from social laws to structures, and notions of universality and totality). They emerge from a number of very different fields, including network theories in the physical, natural, and social sciences; some strands of thought in geography, cognitive science, and informatics/ computing; complexity theories in biology, particularly theories of emergence and self-organization; Deleuze and Guattari's "neo-realism" (particularly their theory of multiplicities); and anarchism. These are not altogether new. What is most interesting is that in the context of Latin American social movements, there is a convergence between what is seen as the logic of the movements and the logic of the (new) theorythat is, an ontological shift in theory that resonates with the relational and open-ended aspect of the ontologies of some of the groups with which the theorists are working. This provides an exciting moment for thinking anew about socionatural life, politics, and theory at the same time.

\section{References}

Blaser, Mario. 2007. Bolivia: Los desafíos interpretativos de la coincidencia de una doble crisis hegemónica. In Reinventando la nación en Bolivia: Movimientos sociales, Estado y poscolonialidad, ed. Karin Monasterios, Pablo Stefanoni, and Hervé Do Alto, 11-21<tk>. La Paz: CLACSO/Plural.

- Forthcoming. Storytelling globality: A border dialogue ethnography of the Paraguayan Chaco. Durham, NC: Duke University Press. Cadena, Marisol de la. 2007. Asumir la política indígena en sus propios términos requiere un análisis más allá de lo 'político.' Unpublished manuscript.

Calderón, Fernando. 2007. Inflexión histórica: La situación social-institucional en el cambio político de América Latina? Proyecto Regional: Análisis político y escenarios de corto y mediano plazo para fortalecer la gobernabilidad democrática en América Latina (PAPEP). Buenos Aires: PNUD.

Castro-Gómez, Santiago, and Ramón Grosfogel, eds. 2007. El giro decolonial. Reflexiones para una diversidad epistémica más allá del capitalismo global. Bogotá: Universidad Central/Universidad Javeriana.

Ceceña, Ana Ester. 2008. Derivas del mundo en el que caben todos los mundos. Mexico, DF: Siglo $\mathrm{XXI} / \mathrm{CLACSO}$. 
Dar, Sadhvi, and Bill Cooke, ed. 2008. The new development management: Critiquing the dual modernization. London: Zed Books.

Escobar, Arturo. 2006. An ecology of difference: Equality and conflict in a glocalized world. Focaal-European Journal of Anthropology 47: $120-40$.

Gibson-Graham, J. K. 2006. A postcapitalist politics. Minneapolis: University of Minnesota Press.

Grossberg, Lawrence. 2007. Critical studies in search of modernities. Unpublished manuscript, Chapel Hill.
Lohmann, Larry. 2006. Activism, expertise, commons. Development Dialogue 47: 149-81.

Paco, Félix Patzi. 2004. Sistema comunal: Una propuesta alternativa al sistema liberal. La Paz: CEA.

Sousa Santos, Boaventura de. 2007. The rise of the global left. London: Zed Books.

Strathern, Marilyn. 1996. Cutting the network. Journal of the Royal Anthropological Institute 2: 517-35.

Zibechi, Raúl. 2006. Dispersar el poder: Los movimientos como poderes antiestatales. Buenos Aires: Tinta Limón. 